\title{
ГОСУДАРСТВЕННО-КАПИТАЛИСТИЧЕСКИЙ И КООПЕРАТИВНЫЙ ПУТИ В ОБЩЕСТВО БУДУЩЕГО И ВЫБОР В.И.ЛЕНИНА
}

\section{(C) 2021 Будович Юлия Ивановна}

доктор экономических наук, доцент, профессор Департамента экономической теории Финансовый университет при Правительстве Российской Федерации, Россия, Москва

E-mail: JBudovich@fa.ru

ORCID: https://orcid.org/0000-0001-8691-947X

\section{(c) 2021 Будович Маргарита Сергеевна}

кандидат экономических наук, доцент Департамента экономической теории Финансовый университет при Правительстве Российской Федерации, Россия, Москва

E-mail:MSBudovich@fa.ru

ORCID: https://orcid.org/0000-0002-7234-1408

В статье показывается, что выбор В.И.Лениным и партией большевиков государственнокапиталистического пути перехода к коммунизму противоречил истинному марксизму - начиная с первого тома «Капитала» и до последних работ включительно К. Маркс последовательно отстаивал кооперативный путь в общество будущего - и был обоснован стремлением к безраздельной и бессрочной власти в стране. В статье доказывается, что настоящей пролетарской революцией была не Октябрьская, а Февральская революция 1917 года, а истинно марксисткой партией была партия не большевиков, а социал-революционеров (эсеров), благодаря которой сразу же после Февраля в стране стал реализовываться кооперативный путь перехода к обществу будущего - в виде рабочего контроля, или движения фабрично-заводских комитетов.

Ключевые слова: нефинансовая экономика, кооперативный путь, истинный марксизм, рабочий контроль, фабрично-заводские комитеты.

В наших работах было показано, что из двух путей, предлагавшихся К.Марксом и Ф.Энгельсом для перехода к коммунизму государственно-капиталистического (на основе предприятий, находящихся в собственности государства и централизованно управляемых последним) и кооперативного (на основе предприятий, находящихся в собственности их трудовых коллективов, т.е. производственных кооперативов (ПК), добровольно объединяющихся в союзы разного уровня с целью планомерной организации народного хозяйства) [11, с. 257] - второй с точки зрения теории нефинансовой экономики является более эффективным [11, с. 253]. Было показано, что основоположники марксизма выбирали как экономисты кооперативный путь, и именно он соответствует истинному марксизму, а как политики - менее эффективный, государственно-капиталистический путь, поскольку он позволяет революционной партии (и ее вождям), в случае победы в ходе революции возглавляемых ею трудящихся, осуществлять безраздельное и бессрочное управление страной, к которому К.Маркс и Ф.Энгельс стремились, так как мечтали лично возглавить не только падение «старого» мира, но и его полное уничтожение [2, с. 484-486].

Цель настоящей статьи - показать, что выбор В.И.Ленина в пользу государственнокапиталистического пути также имел не экономический, а политический характер, объяснить этим замалчивание В.И.Лениным, а за ним - и советской партийной и политикоэкономической литературой, существования в марксизме рассмотренной выше неудобной коллизии, а главное - показать, что последовательному (истинному) марксизму соответствует кооперативный путь, который К. Маркс неизменно отстаивал, начиная с первого тома «Капитала» (написано в середине 1860-х гг.), обосновать в связи с этим необходимость пересмотра традиционных: оценок характера Февральской революции 1917 года и партии эсеров, представлений о роли в развитии рабочего контроля творчества рабочих масс, Временного правительства и партии эсеров и об отношении В.И. Ленина к ПК по- 
сле Октября 1917 г.

В первом написанном В.И.Лениным (в 1895 г.) программном документе социалдемократической партии зафиксирован государственно-капиталистический путь перехода к коммунизму (см. ниже). Однако В.И. Ленин в 1895 г. прекрасно знал, что истинному марксизму соответствует кооперативный путь.

По нашему мнению, В.И.Ленин мог узнать о том, что К. Маркс является сторонником кооперативного пути, даже еще до того, как решил посвятить себя революции. Его брат Александр, один из руководителей террористической фракции «Народной воли», приезжая летом 1885 и 1886 гг. в Симбирск, где жила семья Ульяновых (будущему вождю в то время было 15 и 16 лет соответственно), привозил с собой первый том «Капитала», и тогда же В.И.Ленин начал знакомиться с данным произведением [16, с. 5]. А первое и, причем, легальное русское издание первого тома «Капитала», вышедшее в свет в 1872 г., было переводом с его первого издания на немецком языке, появившегося в 1867 г. [8], т.е. с варианта книги, не «подправленного» Ф.Энгельсом, в котором в главе двадцать четвертой отчетливо фигурировал именно кооперативный путь перехода к обществу будущего (см. ниже). И В.И.Ленин, интересуясь, чем завершится развитие капиталистического общества, мог самостоятельно узнать об этом пути. Еще более вероятно, что сам А.Ульянов мог обратить внимание брата на то, что истинному марксизму соответствует кооперативный путь, так как народовольцы очень гордились тем, что их программу, в которой значился тот же кооперативный путь для преобразования как сельской (посредством общин, но минуя капитализм), так и городской (путем передачи фабрик и заводов рабочим) экономики, одобрил сам К.Маркс [26], почему А.Ульянов, собственно говоря, и возил с собой «Капитал» (первый том), в котором этот путь был зафиксирован. Вообще, получается, что в России «Капитал» был настольной книгой народника в неменьшей степени, чем социал-демократа.

В любом случае пристальное знакомство с марксистской литературой В.И.Ленин начал с «Капитала». В жизнеописаниях В.И.Ленина подчеркивается, что он начал серьезно изучать «Капитал» осенью 1888 г. [16, с. 8]. Это было начало периода его пребывания в Казани (октябрь 1888-май 1889 г.). Туда В.И. Ленину было дозволено вернуться из более чем годовой ссылки в д. Кокушкино (с декабря 1887 г.), в которую он попал из той же Казани после исключения из Казанского университета за участие в студенческих выступлениях, и там он знакомится с участниками многих революционных кружков, где читались в подлинниках и переводах произведения К. Маркса, а также труды Г.В.Плеханова, направленные против народничества, прежде всего «Наши разногласия» [16, с. 8-10].

О кооперативном пути как элементе научного социализма и о приверженности ему К. Маркса «ранний» (до 1895 г.) В.И.Ленин мог узнать и из работы К. Маркса «Критика Готской программы» (1875). На нее вождь ссылается в своей ранней полемической работе «Что такое «друзья народа» и как они воюют против социал-демократов?» (написано весной - летом 1894 г.) [12, с. 332], причем как раз на то место этой работы (Марксову критику того требования германской рабочей партии), где получает отражение представление «позднего» К. Маркса о кооперативном пути перехода к коммунизму. Это - критика требования германской рабочей партии учреждения производительных товариществ (т.е. ПК) с государственной помощью, которые должны быть вызваны к жизни, как в промышленности, так и в земледелии, в таком объеме, чтобы из них возникла социалистическая организация совокупного труда, но критика не за саму идею кооперативного пути, а за «фантазии» Фердинанда Лассаля (основоположника немецкой социал-демократии), в соответствии с которыми «социалистическая организация совокупного труда» возникнет не в результате революции, а из помощи буржуазного государства, оказываемой производительным товариществам [20, с. 25-26].

В работе «Что такое «друзья народа»...?» В. И. Ленин защищает от нападок Н. К. Михайловского основанное К. Марксом в 1864 г. Международное Товарищество Рабочих (международный союз социалистических партий, или Первый Интернационал, существовавший в 1864-1876 гг.) [12, с. 154-156], филиалом продолжения которого (Второго Интернационала, основанного в 1889 г.) позиционировала себя российская социал-демократия во главе с Г.В.Плехановым, к которой относил себя и В.И.Ленин. Представляется, что в таком случае В.И.Ленин, сам требующий от своих оппонентов полного знания обсуждаемых предметов, не мог не знать программу Первого Интернационала (на докумен- 
ты этой организации В.И.Ленин ссылается и в других своих ранних работах). А между тем, в «Учредительном манифесте Международного Товарищества Рабочих...», написанном К. Марксом в том же 1864 г., отмечается, что рабочие, основывавшие кооперативные фабрики без всякой поддержки, после событий 1848 г. (речь идет о европейских революциях 1848-1849 гг.примеч. авт.), доказали, что производство в крупных размерах и ведущееся в соответствии с требованиями современной науки, возможно и в отсутствии класса хозяев, пользующихся наемным трудом (семена кооперативной системы, отмечает К. Маркс, были посеяны в Англии Робертом Оуэном), в связи с чем наемный труд должен уступить место ассоциированному (кооперативному) труду, выполняемому добровольно, с готовностью и воодушевлением, и, чтобы магнаты земли и капитала не воздвигали всевозможные препятствия на пути именно такого (кооперативного) освобождения труда, обязанностью рабочего класса является завоевание политической власти [17]. Заметим, что образование рабочими-единоличниками ПК с нуля есть кооперативный путь движения к коммунизму, минуя капитализм, так что одобрение К.Марксом программы народников (см. выше) вполне закономерно.

В своих ранних произведениях В.И.Ленин не ссылается на работу К. Маркса, в которой его кооперативный идеал будущего непосредственно именуется коммунизмом. Этой работой является «Гражданская война во Франции» (1871). Как пишет в ней К. Маркс, Коммуна хотела экспроприировать экспроприаторов, превратив средства производства, землю и капитал, служащие в настоящее время орудиями порабощения и эксплуатации труда, в орудия свободного ассоциированного труда - но ведь это коммунизм. Если кооперативное производство должно вытеснить капиталистическую систему, если объединенные кооперативные товарищества организуют национальное производство по общему плану, взяв руководство им в свои руки и прекратив постоянную анархию и периодические конвульсии, неизбежные при капиталистическом производстве,- не будет ли это коммунизмом? [19, с. 346-347]. При этом исследователи жизни В.И. Ленина отмечают особое отношение вождя, интересовавшегося историей Парижской коммуны 1871 года, к данному произведению К.Маркса, которое он считал непревзойден- ным источником данных по истории Коммуны. В.И.Ленин, до этого (в 1904 г.) написавший «Три конспекта доклада о Парижской коммуне», в 1905 г., находясь в Женеве, по предложению одесского издательства «Буревестник» выступил редактором легального издания перевода на русский язык «Гражданской войны во Франции», сделанного издательством с юбилейного издания, выпущенного Ф. Энгельсом в 1891 г., внеся в перевод 530 правок [7]. Мы смеем предположить, что и «ранний» В.И.Ленин был знаком с данным произведением К. Маркса. Дело в том, что «Гражданская война во Франции» была одним из первых легально изданных в России на русском языке произведений К.Маркса (наряду с первым томом «Капитала»). Известно, что эта книга свободно выдавалась читателям Императорской публичной библиотеки в Санкт-Петербурге, в частности, еще в 1870-е годы, когда (в 1873 и 1877-1879 гг.) ее читателем был сам Г.В.Плеханов [9, с. 25-26], а с 31 августа 1893 г. В.И.Ленин занимается революционной деятельностью уже в столице (см. ниже).

Кстати, в «Гражданской войне во Франции» представлена идея «задушенного» большевиками в 1918 г. «рабочего контроля» (непосредственного управления предприятиями их трудовыми коллективами в лице фабричнозаводских комитетов, или фабзавкомов, ФЗК), возникшего сразу после победы Февральской революции 1917 года и принявшего массовый характер (с точки зрения доли охваченных им предприятий), который и был воплощением в жизнь истинно марксистского, кооперативного пути перехода к коммунизму. Рабочий контроль вводился на предприятиях, в том числе, вследствие попыток администрации или хозяев остановить производство в целях борьбы с рабочими, выдвигавшими требования введения 8-часового рабочего дня, удаления неугодной администрации и т.д. В своей книге К. Маркс отмечает, что рабочим товариществам Парижской коммуной были переданы все закрытые мастерские и фабрики, владельцы которых бежали или приостановили работы [19, с. 351]. Интересно, что В.И.Ленин не забыл отметить данный факт в своих Конспектах (1904): «Передача брошенных фабрик рабочим товариществам» [14, с. 487].

В работе «Что такое «друзья народа»...?» В.И.Ленин даже выступает защитником кооперативного пути перехода к коммунизму. Отбиваясь в ней от нападок народника Н.К. Михай- 
ловского на диалектический метод К.Маркса (на то, что «идеал» Маркса об общинности земли и капитала в смысле его неизбежности и несомненности держится только на конце гегелевской трехчленной цепи [12, с. 169]), В.И.Ленин ссылается на свой собственный перевод той части «Анти-Дюринга», где от аналогичных нападок на метод К.Маркса г-на Дюринга отбивался сам Ф.Энгельс [12, с. 169-174]. И согласно этому переводу, на абсолютную точность которого обращает внимание В.И.Ленин, экспроприация экспроприаторов в первом томе «Капитала» К. Маркса, на дословном цитировании которого основывается соответствующее место произведения Ф.Энгельса, есть переход от капиталистической именно к общинной собственности на землю и средства производства. Вот дословная цитата из соответствующего перевода, сделанного В.И.Лениным: «У Маркса значится: «Это - отрицание отрицания. Оно снова создает индивидуальную собственность, но на основании приобретений капиталистической эры - кооперации свободных работников и их общинного владения землей и произведенными ими средствами производства...». Таким образом, порядки, созданные экспроприацией экспроприаторов, характеризуются как восстановление индивидуальной собственности на основании общинного владения землей и созданными самими работниками средствами производства. Для всякого, кто понимает немецкий язык (и русский тоже, г. Михайловский, потому что перевод совершенно точен), это означает, что общинная собственность простирается на землю и другие средства производства, а индивидуальная собственность на остальные продукты, т.е. на предметы потребления» [12, с. 171]. Важно отметить, что и народник Н.К.Михайловский не сомневался в верности Марксова идеала, а сутью его возражений было то, что в условиях России переход от индивидуальной собственности к общинной может быть совершен напрямую, т.е., минуя капиталистическую собственность (первое отрицание), с чем только, а не с собственно переходом к общине, и был не согласен В.И.Ленин. Кстати, В.И.Ленин здесь (как и его оппонент) демонстрирует незнание позиции К.Маркса о возможности общинного перехода в России к социализму на селе минуя капитализм, с которой его мог познакомить еще А. Ульянов (см. выше).

При этом «ранний» В.И.Ленин уже хорошо знал, что в свое время в «Манифесте Коммунистической партии» (1848) основоположники марксизма высказывались за государственнокапиталистический путь перехода к коммунизму - шаг за шагом вырвать у буржуазии весь капитал, централизуя его в руках государства [18, с. 446]. Теоретически В. И. Ленин мог ознакомиться с Манифестом еще в период пребывания в Казани (октябрь 1888-май 1889 г.), где приступил к знакомству с марксисткой литературой. Да и первым произведением основоположников марксизма, переведенным за рубежом на русский язык Г.В.Плехановым и его группой и отправленным контрабандой в Россию еще в мае 1882 г., был как раз Манифест, который в революционных кружках из-за его популярности многократно переиздавался и переписывался от руки [9, с. 35-37]. Однако, известно, что, проживая потом в Самарской губернии (май 1889-август 1893 г.), В.И.Ленин сам перевел Манифест на русский язык [16, с. 8-16], что может говорить о том, что с данным произведением вождь познакомился только тогда.

В труде «Что такое «друзья народа...?» В.И. Ленин ссылается на работу Ф. Энгельса «Развитие капитализма из утопии в науку» (1880) [12, с. 165], в которой Ф.Энгельс отходит от истинного марксизма по вопросу о форме собственности при переходе к коммунизму, снова выступая за государственно-капиталистический путь. Как писал Ф.Энгельс, капиталистический способ производства, заставляя все более и более превращать в госсобственность крупные обобществленные средства производства, сам указывает этот путь - пролетариат берет государственную власть и передает средства производства прежде всего в государственную собственность [20, с. 224]. И «прежде всего» здесь лишнее, так как далее Ф. Энгельс подтверждает, что передача средств в производства в руки государства является именно конечным, а не промежуточным, пунктом преобразования отношений собственности [20, с. 229]. Кстати, в письме Августу Бебелю от 20-23 августа 1886 г. Ф. Энгельс вновь предстает поборником кооперативного пути, допуская сохранение госсобственности на средства производства лишь на первое время - чтобы особые интересы кооперативного товарищества не возобладали над интересами общества в целом, развивает теорию кооперативного строительства в духе мероприятий Парижской коммуны 1871 года предлагает не создавать мелкие кооперативы без 
помощи (как предлагал Шульце-Делич) или с помощью государства (как предлагал Лассаль), а давать кооперативам вступать во владение уже действующими средствами производства, подобно тому, как Парижская коммуна требовала от рабочих запуска предприятий, оставленных хозяевами, на кооперативных началах, в частности сдавать кооперативным товариществам в аренду крупные поместья [21, с. 360-361].

В.И.Ленин не мог не заметить соответствующего отхода от истинного марксизма в программных документах социал-демократов, написанных Г. В. Плехановым. В программе группы «Освобождения труда» (1884) числилось экономическое освобождение рабочего класса путем перехода всех средств и продуктов производства в коллективную собственность трудящихся (а еще до революции - государственная помощь производительным ассоциациям, организующимся во всевозможных отраслях земледелия, добывающей и обрабатывающей промышленности крестьянами, горными, фабричными и заводскими рабочими, кустарями и т.д.) [30], а во «Втором проекте программы русских социалдемократов» (1887, опубликовано в 1888 г.) освобождения труда от гнета капитала предполагается достигнуть уже путем перехода всех средств и предметов производства в общественную собственность (правда, с сохранением требования о помощи буржуазного государства производительным ассоциациям) [3]. Как оправдывал Г.В Плеханов этот шаг в в известных В.И.Ленину «Наших разногласиях» (1884), «Запад» стремится к обращению средств производства в государственную, а не в общинную собственность [25].

Не мог В.И. Ленин не заметить отказа от кооперативного пути в программе наиболее мощной и революционной, социал-демократической партии Германии, принятой в 1891 г. (кооперативный путь был зафиксирован в ее Готской программе - см. выше), в которой теперь также фигурирует государственно-капиталистический путь - превращение капиталистической частной собственности (земли, шахт и рудников, сырья, орудий, машин, транспортных средств) в собственность общественную [31].

По нашему мнению, «ранний» В.И.Ленин не только ясно видел непоследовательность социал-демократов, да и Ф. Энгельса, в вопросе о форме предприятий при переходе к коммунизму, их отход в его решении от истинного марксизма, но и прекрасно понимал причины включения в программные документы революционных партий государственно-капиталистического пути перехода к коммунизму - это претензии вождей социал-демократов на диктаторскую роль в будущем коммунистическом социальном перевороте. В.И.Ленин, талантливый полемист, мог бы превратить тему извращения истинного марксизма в вопросе о форме собственности при переходе к коммунизму в основу для написания длинного ряда ярких полемических работ, но ему было абсолютно невыгодно даже упоминать об этих извращениях, как и акцентировать внимание на взглядах К. Маркса по данному вопросу, поскольку к такому же извращению и в тех же целях он собирался прибегнуть сам.

Таким образом, еще недавно фактически защищавший общинный путь перехода к коммунизму («Что такое «друзья народа...?», написано весной - летом 1894 г.) В.И.Ленин вдруг становится поборником государственнокапиталистического пути перехода к обществу будущего. В «Проекте программы» социалдемократической партии, написанном В.И.Лениным в тюрьме в декабре (позднее 9 (21) числа) 1895 г., куда он попал в результате разгрома жандармами в Санкт-Петербурге в ночь на 9 декабря 1895 г. возглавляемого им «Союза борьбы за освобождение рабочего класса» [16, с. 34], в качестве соответствующего пути значится (вместе с предварительным переходом политической власти в руки рабочего класса, под которым он тогда понимал только пролетариат) передача всей земли, орудий, фабрик, машин и рудников в руки всего общества для устройства социалистического производства [13, с. 83-84].

На наш взгляд, эта внезапная метаморфоза, как и в случае с основоположниками марксизма (в «Принципах коммунизма», написанных Ф. Энгельсом в конце октября - ноября 1847 г., значился еще кооперативный путь в форме «общности имущества» [18, с. 330], представляющей собой, как ясно из других произведений Ф.Энгельса, производственно-потребительские коммуны [22], тогда как в Манифесте, написанном основоположниками марксизма в декабре 1847 - январе 1848 г. и к тому же официально трактуемом лишь литературной переработкой Принципов, фигурирует уже государственно-капиталистический путь (см. выше)) является следствием стремительного взлета накануне революционных событий революционно-партийной карьеры автора программного документа, мечтающего 
лично не просто поколебать, но и до основания разрушить «старый» мир, что позволяет обеспечить государственно-капиталистический путь перехода к коммунизму, дающий партии победившего пролетариата экономическую власть в стране, реализуемую через подчиненное партии государство.

И на самом деле, В.И.Ленин мечтал лично «расправиться» с существовавшим строем, что дает нахождение у власти в стране, причем диктаторской. По мнению экспертов (Задорожный, 2020), по настоящему В. И. Ленина увлекало только неутомимое стремление к власти, причем власть интересовала его исключительно как способ осуществления идеи, которая владела им с юности - создания и обеспечения существования рабоче-крестьянского государства [6]. Это подтверждает и личный секретарь И. В. Сталина Б.Бажанов: у В.И.Ленина была маниакальная жажда власти - во что бы то ни стало к власти прийти и у власти удержаться, причем В.И.Ленин жаждал власти в целях построения коммунизма в стране [23].

И к моменту написания «Проекта программы» В.И.Ленин уже понимает (это понимание, очевидно, не пришло в тюрьме, а состоялось гораздо раньше), что имеет реальную возможность стать вождем революционной пролетарской партии национального масштаба, рассчитывающей на победу в будущей революции возглавляемого ею пролетариата. 31 августа 1893 г. В.И.Ленин прибывает в столицу страны Санкт-Петербург [16, с. 16], где быстро становится лидером столичных социал-демократов и фактически таковым в масштабах страны, а возглавляемая им организация овладевает успешными приемами управления революционной рабочей массой. За полтора года пребывания в столице В.И.Ленин создал и возглавил революционную организацию («Союз борьбы...»), основанную на принципах централизма и строгой дисциплины, организовал издание листков, в частности листка, благодаря влиянию которого рабочие Нового Порта добились уступок от администрации, создал марксистские кружки на всех крупных заводах Санкт-Петербурга, установил связи с социал-демократическими организациями Москвы, Киева, Ярославля, Владимира, Твери, Нижнего Новгорода, Минска и т.д. и фактически договорился о том, что возглавит их идейно - путем снабжения газетой «Рабочее дело», выступил представителем социал-демократов, находившихся в стране, перед находившейся за границей группой Г.В.Плеханова «Освобождение труда», организовал удачную забастовку рабочих на заводе Торнтона [16, с. 28-33].

При этом приезд В.И.Ленина в СанктПетербург имел место накануне подъема массового рабочего движения [16, с. 17].

Таким образом, подобно тому, как К. Маркс и Ф.Энгельс в период написания Манифеста становились - накануне европейских революций 1848-1849 гг.- лидерами наиболее влиятельной революционной рабочей партии, а именно «Союза коммунистов», причем рассчитывавшей на успех революции, которую она собиралась возглавить, В.И.Ленин в период написания «Проекта программы» становился - накануне, правда, так и не начавшейся, пролетарской революции - лидером рабочей партии, также рассчитывавшей на успех революции, которую она намеревалась возглавить. Учитывая же мессианские амбиции вождя, это и могло послужить причиной включения в программу партии государственно-капиталистического пути перехода к коммунизму.

С требованием передачи средств производства в собственность государства в партийной программе (в программе РСДРП, принятой в 1903 г.) и вошла возглавляемая В.И.Лениным партия большевиков в революционный 1917 г. В ней фигурировали замена частной собственности на средства производства и обращения общественной [29].

После того, как В.И.Ленин включил в программу социал-демократов государственнокапиталистический путь перехода к коммунизму, ему не оставалось ничего другого, как начать скрывать «кооперативные» взгляды К.Маркса. Кстати, среди российских социал-демократов традиция скрывать «неудобные» взгляды К. Маркса была заложенная еще членами группы «Освобождение труда». Известно, что Г.В.Плеханов и В.И. Засулич не только замалчивали, но и отрицали наличие у К. Маркса работ, в которых он писал о возможности движения России к социализму через крестьянскую общину, минуя капитализм [33].

Пожилые люди согласятся с тем, что из произведений В.И.Ленина, по крайней мере рекомендовавшихся в СССР к прочтению обучающимся, в том числе и из широкого набора для углубленного изучения ленинизма, даже тех, где говорится о кооперативах (коммунах, артелях и 
т.д.), было абсолютно неясно, что в марксизме был также представлен кооперативный путь перехода и коммунизму, и что «поздний» К. Маркс выступал именно за него. Естественно, на этом вопросе не заострялось внимание в советской партийной и политико-экономической литературе, издававшейся, по крайней мере, после смерти И.В.Сталина (в 1953 г.). Замалчивание данного вопроса было налажено так, что даже после ознакомления с произведениями самого К.Маркса, в которых фигурировал кооперативный путь, не приходило на ум, что именно он соответствует в вопросе коммунистического преобразования отношений собственности истинному марксизму. Соответственно, никто не мог и предположить, что истинному марксизму противоречил предписанный принятой XXII съездом КПСС в 1961 г. третьей Программой КПСС переход к 1980 г. к единой общенародной форме собственности в связи с созданием материально-технической базы коммунизма и построением в СССР в основном коммунистического общества [27].

Раскрытие неистинности марксизма большевиков в вопросе о форме хозяйствования для перехода к коммунизму побуждает к дальнейшему исследованию данного вопроса и к переоценке исторических событий и революционных движений по его результатам. Как было показано выше, превращение стран в республики производственных кооперативов, по К.Марксу, должно было происходить путем не только передачи действующих средств производства товариществам рабочих, но и формирования рабочими-единоличниками (с помощью или без помощи государства) производственных кооперативов с нуля. При этом, поскольку рабочиеединоличники (как и трудовые крестьяне в России) стремились к созданию таких ассоциаций, а государство этому препятствовало, рабочиеединоличники, как и пролетариат, т.е. наемные рабочие, согласно «позднему» К. Марксу, также относятся к революционному классу. Примеры того, как рабочие-единоличники революционного (в 1848 г.) Парижа (портные - 20 тыс. чел., башмачники - 30 тыс. чел., жестянщики, лудильщики) стремились к объединению в ПК в масштабах целых видов деятельности, а государство им мешало (в частности, разогнало ПК портных, разместившийся в зданиях тюрьмы Клиши, освободившейся вследствие ликвидации заключения за долги), приводит Ф. Лассаль в своем знаменитом полемическом произведении «Капитал и труд. Г.Бастиа-Шульце Делич. Экономический Юлиан» (1864) [10, с. 281-282]. В программных же документах большевиков революционным классом числился только пролетариат, партия (социал-демократов) является сознательной выразительницей классового движения только пролетариата, условием социальной революции является диктатура только пролетариата и т.д., например в программе РСДРП (1903) [29].

Изучение же программных документов другой российской революционной социалистической партии, возникшей на базе народнических групп, а именно партии социал-революционеров (эсеров, ПСР), партии, с которой так яростно боролись большевики, говорит о том, что истинно марксистской партией была не РСДРП или входящая в нее партия большевиков во главе с В.И.Лениным, а именно ПСР. В программе ПСР (1906) революционным числился весь рабочий класс - от пролетариата до трудового крестьянства, т.е. включая и трудящихся-единоличников, партия считает себя выразителем интересов всего рабочего класса, а не только пролетариата, обобществление собственности в городе понималось в традиционном народническом духе - как передача предприятий в собственность их трудовых коллективов, поскольку программа предостерегала рабочий класс против «государственного социализма», или госкапитализма, сосредотачивающего производство и торговлю в руках правящей бюрократии ради ее фискальных и политических целей, условием социального переворота считается диктатура всего рабочего класса [28]. Соответственно, критика В.И.Лениным эсеров, как и до этого - народников, в действительности была борьбой с истинным марксизмом.

Этот факт позволяет предположить, что пролетарской революцией в действительности была не Октябрьская, а Февральская революция 1917 года, главную роль в осуществлении которой сыграли эсеры, и сразу после завершения которой началась передача фабрик и заводов в руки рабочих в виде массового введения на предприятиях рабочего контроля, представлявшего собой реализацию кооперативного пути перехода к коммунизму в городской экономике, за который выступал К. Маркс. Тем более, что в феврале 1917 г. царское правительство было свергнуто, в отличие от того, как в октябре того же года было 
свернуто Временное правительство, в состав которого входили и которое даже возглавляли эсеры, при широком участии рабочих масс. Так, 23 февраля волнения в Санкт-Петербурге, переросшие затем в революцию, начали рабочиетекстильщики, которых насчитывалось в городе 44 тыс. [32]. Октябрьская революция 1917 года в таком случае есть изменение расклада сил внутри лагеря социалистов в пользу большевиков, осуществленное с целью смены пути перехода к новому обществу.

Исходя из вышеизложенного, выглядит необоснованным традиционное представление о рабочем контроле как о стихийном движении рабочих, обусловленном их предыдущим опытом самоорганизации (создания профсоюзов, потребительских обществ, больничных касс и т.д.) [32] и традиционными стереотипами социального поведения - общинностью и коллективизмом, присущими русскому крестьянству, из среды которого непосредственно происходила основная масса рабочих [33]. Стихийности не соответствует начало данного рабочего движения сразу же после завершения Февральской революции 1917 г. (в начале марта) и одновременно на множестве предприятий. Необходимо тщательно изучить роль в развитии рабочего контроля Временного правительства и партийной агитации эсеров на фабриках и заводах. Развитие рабочего контроля могло быть результатом целенаправленных мер Временного правительства. О существенной роли в его развитии партийной агитации эсеров говорит быстрый рост численности ПСР после Февраля 1917 г., как раз и выступающий следствием бурной партийной агитации. По темпам роста ПСР опережала другие партии - к лету 1917 г. в 62 губерниях, на флотах и фронтах было 436 организаций эсеров общей численностью около 1 млн. чел., в ПСР в тот год вступали целыми фабриками, деревнями, полками [24], что говорит о знании, в частности, теми же рабочими ее программы. Для сравнения, партия большевиков в то время насчитывала всего 50 тыс. чел. [5]. О существенной роли в развитии рабочего контроля агитации эсеров говорит их большинство в начальный период развития рабочего контроля в ФЗК и в Советах Рабочих Депутатов, формировавшихся при активном участии ФЗК. Лишь в мае-июне большевики завоевывают большинство в этих органах, очевидно, благодаря поражениям русской армии на фронтах и лозунгу «Долой войну», о чем говорят результаты выступления В.И. Ленина 12 мая 1917 г. на Путиловском заводе (когда лидер эсеров, министр земледелия В. Чернов под соответствующие возгласы рабочих был вынужден покинуть заводской двор) [1]. У эсеров были и все возможности для ведения такой агитации, прежде всего наличие необходимой поддержки во Временном правительстве - пост министра внутренних дел в нем получил эсер Н.Авксентьев, а юстиции - эсер А. Керенский (будущий премьер-министр) [5]. В настоящее время лишь некоторые исследователи считают, что рабочий контроль был инспирирован эсерами, например В. П. Булдаков [33].

Установленное выше отношение В.И.Ленина к кооперативному пути перехода к коммунизму позволяет утверждать, что В.И.Ленин реально никогда не рассматривал кооперативный путь в качестве возможного для нашей страны, в частности сразу после Октябрьской революции 1917 года, как считает, например, В.И.Дьяченко [4], а включение им кооперативного пути в «Черновой набросок проекта программы РКП (б)» (написано в марте 1918 г.) принудительное объединение всего населения в потребительско-производительные коммуны [15, с. 74], и «Очередные задачи советской власти» (написано 13-26 апреля 1918 г.) - социалистическое государство может возникнуть лишь как сеть производительно-потребительских коммун [15, с. 185], является результатом не творческого поиска вождем лучшего пути перехода к новому обществу и перемены его отношения к рабочему контролю, а всего лишь способом введения в заблуждение рабочих с целью заручиться их поддержкой в период времени, когда власть большевиков висела на волоске.

\section{Библиографический список}

1. Борьба большевиков за массы после Февральской революции / Илья Винштейн. URL: http://www.winstein. org/publ/36-1-0-2145 (дата обращения: 18.01.2021).

2. Будович Ю.И., Будович М. С. Государственно-капиталистический и кооперативный пути перехода к коммунизму и партийная программа // Экономические науки. 2020. № 12 (193). C. 479-487. DOI: 10.14451/1.193.479. 
3. Второй проект программы русских социал-демократов / libelli.ru 2003-2020. URL: http://libelli.ru/works/ pi1-2.htm (дата обращения: 02.01.2021).

4. Дьяченко В.И. Марксизм о первой (начальной) фазе коммунизма / Инициативная группа по формированию движения За Коммунистическое развитие в XXI веке. Из царства необходимости - в царство свободы. 05.02.2016. URL: http://communism21.org/abc/16 (дата обращения: 24.09.2020).

5. Еремин В. Как 50 тысяч большевиков победили миллион эсеров / Livejournal. 13.06.2020. URL: https:// historical-fact.livejournal.com/214685.html (дата обращения: 18.01.2021).

6. Задорожный А. Триумф, крах и трагедия красного диктатора / ZNAK. 22.04.2020. URL: https://www.znak. com/2020-04-22/kak_lenin_proigral_svoy_posledniy_i_reshitelnyy_boy (дата обращения: 04.10.2020).

7. Каганова Р.Ю. Ленин во Франции. С. 49 / ЛИТМИР. Электронная библиотека. URL: https://www.litmir.me/ $\mathrm{br} / \mathrm{b}=200940 \& \mathrm{p}=49$ (дата обращения: 28.12.2020).

8. Каратаев Н. Исторические заметки. Первые переводчики «Капитала» / ЛИБМОНСТР. Историк-марксист. 1940. № 11 (087). С. 100-104. URL: https://libmonster.ru/m/articles/view/Исторические-заметки-ПЕРВЫЕПЕРЕВОДЧИКИ-КАПИТАЛА (дата обращения: 21.01.2021).

9. Курбатова И. Н. Начало распространения марксизма в России: Лит.-изд. деятельность группы «Освобождение труда».-М.: Мысль, 1983. 268 с.

10. Лассаль Ф. Капитал и труд. Г. Бастиа-Шульце Делич. Экономический Юлиан.- СПб, Издание В. И. Яковенко, 1905. 333 (VIII) c.

11. Лебедев К.Н. «Финансовый» характер собственности на средства производства в СССР и кризис советской экономики // Экономические науки. 2020. № 11 (192). С. 250-259. DOI: 10.14451/1.192.250.

12. Ленин В.И. Полное собрание сочинений. Издание пятое. Том 1.- М.: Издательство политической литературы, 1967. 663 (XXIV) с.

13. Ленин В. И. Полное собрание сочинений. Издание пятое. Том 2.- М.: Издательство политической литературы, 1967. 677 (XIII) с.

14. Ленин В.И. Полное собрание сочинений. Издание пятое. Том 8.- М.: Издательство политической литературы, 1967. 666 (ХХ) с.

15. Ленин В. И. Полное собрание сочинений. Издание пятое. Том 36.- М.: Издательство политической литературы, 1969. 742 (XXVI) с.

16. Ленин Владимир Ильич. Краткий очерк жизни и деятельности.- М.: Государственное издательство политической литературы, 1942.298 с.

17. Маркс К. Учредительный манифест международного товарищества рабочих, основанного 28 сентября 1864 г. на публичном собрании, состоявшемся в Сент-мартинс-холле, Лонг-эйкр, в Лондоне / K2X2.INFO. Библиотека. URL: http://www.k2x2.info/filosofija/sobranie_sochinenii_tom_16/p4.php (дата обращения: 03.01.2021).

18. Маркс К., Энгельс Ф. Сочинения. Издание второе. Том 4.- М.: Государственное издательство политической литературы, 1955.616 (XIV) с.

19. Маркс К., Энгельс Ф. Сочинения. Издание второе. Том 17.- М.: Государственное издательство политической литературы, 1960. 842 (XXVIII) с.

20. Маркс К., Энгельс Ф. Сочинения. Издание второе. Том 19. - М.: Государственное издательство политической литературы, 1961. 671 (XXVI) с.

21. Маркс К., Энгельс Ф. Сочинения. Издание второе. Том 36. - М.: Государственное издательство политической литературы, 1964. 806 (XXIV) с.

22. Маркс К., Энгельс Ф. Собрание сочинений. Том 42 // https://www.marxists.org/russkij/marx/cw/ (дата обращения: 04.12.2020).

23. Олейник И. Ленин глазами Бориса Бажанова (личного секретаря Сталина) / 14.02.2012. URL: https://www. respectme.ru/blog/378 (дата обращения: 04.10.2020).

24. Партии левых и правых эсеров, меньшевиков / і Инфопедия. Для углубления знаний. URL: https://infopedia. su/3x137d.html (дата обращения: 24.01.2021).

25. Плеханов Г.В. Наши разногласия. Сочинения. Том II / marxists.org. URL: https://www.marxists.org/russkij/ plekhano/Vol2/ch04/ch040.html (дата обращения: 04.01.2021).

26. Программа исполнительного комитета партии «Народная воля». URL: https://narovol.narod.ru/document/ progamIK.htm (дата обращения: 03.01.2021).

27. Программа Коммунистической партии Советского Союза. Принята XXII съездом КПСС в 1961 году (третья в истории Партии). URL: http://aleksandr-kommari.narod.ru/kpss_programma_1961.htm (дата обращения: 12.10.2020). 
28. Программа Партии социалистов-революционеров / Музей истории российских реформ имени П.А. Столыпина // 1906 г. URL: http://xn - e1aаejmenocxq.xn - p1ai/node/13693 (дата обращения: 13.01.2021).

29. Программа Российской социал-демократической рабочей партии. 1903 г. / Музей истории российских реформ имени П.А. Столыпина // http://xn - e1aаejmenocxq.xn - p1ai/node/13690 (дата обращения: 23.09.2020).

30. Программа социал-демократической группы «Освобождение Труда» / Marxists.org. URL: https://www. marxists.org/russkij/plekhano/Vol2/ch05.html (дата обращения: 02.01.2021).

31. Программа Социал-демократической партии Германии (Германия. 14-20 октября 1891) / Исторический факультет МГТУ. Иллюминаты.ru. URL: http://www.illuminats.ru/component/content/article/18-2009-10-2217-04-55/476-program-of-the-social-democratic-party-of-germany (дата обращения: 06.01.2021).

32. Фабзавкомы - рабочая демократия в действии / ВРАГ КАПИТАЛА. URL: https://1917.com/History/ HRR/1082643581.html (дата обращения: 06.10.2020).

33. Чураков Д. О. Рабочее самоуправление в России. Фабзавкомы и революция. 1917-1918 годы. URL: https:/ kartaslov.ru/_Д_О_Чураков_Рабочее_самоуправление_в_России_Фабзавкомы_и_революция_1917/2 (дата обращения: 24.01.2021). 